\title{
Erythropoietic Activity in Culture Media Conditioned by Rat Mesangial Cells
}

\author{
Yukitaka Fukushima, Masako Yanagisawa, Tadashi \\ Yasuda, Yasushi Nakamoto and Akira B. Miura \\ The Third Department of Internal Medicine, Akita \\ University School of Medicine, Akita 010
}

\begin{abstract}
Fukushima, Y., Yanagisawa, M., Yasuda, T., Nakamoto, Y. and Miura, A.B. Erythropoietic Activity in Culture Media Conditioned by Rat Mesangial Cells. Tohoku J. Exp. Med., 1989, 157 (2), 153-162_- Using a tissue culture technique we examined erythropoietin (EPO) producing cells in rat glomeruli. In 5 out of 6 independent glomerular cell cultures, EPO activity was found in the mesangial-cell proliferating phase, but not in the epithelial-cell proliferating phase. Therefore, mesangial cells seemed to be EPO producing cells.—_ erythropoietin (EPO); glomerular cell culture; mesangial cell
\end{abstract}

Erythropoietin (EPO) is mainly produced in the kidney (Jacobson et al. 1957). However, the precise site or cell that acts as EPO producer in the kidney has not yet been specifically defined. EPO production has been associated with the glomerular region by morphological findings (Hirashima and Takaku 1962) and by fluorescent antibody studies (Fisher et al. 1965). Goldwasser does not agree that some cells produce a substance unless they are cultured, and that a continued secretion was found in the medium (Erslev and Caro 1984). Glomerular cell cultures have enabled us to study EPO production. The renal glomerulus is composed of at least four cell types: (1) endothelial cells, (2) glomerular epithelial cells, (3) mesangial cells, and (4) parietal epithelial cells (Kreisberg and Karnovsky 1983). Among these types, the common culture technique for normal rat glomeruli yields the growth of glomerular epithelial cells and mesangial cells. These two cell types have a difference in growth time (Foidart et al. 1979).

In the present study utilizing these characteristics, we have assayed EPO activities in culture media from the epithelial to the mesangial growth periods. We found that there were EPO activities only in the culture media of the mesangial cell proliferating phase.

Received August 28, 1987; revision accepted for publication January 20, 1989. 


\section{Materials and Methods}

\section{Glomerular cell culture}

Glomeruli from male Wistar rats were obtained from Shizuoka Experimental Animal Cooperative (Hamamatsu). The kidneys were perfused in situ via the thoracic aorta with phosphate-buffered saline (PBS) to remove blood cells. Renal cortical tissue was removed with scissors, and minced into small pieces. Glomeruli were isolated by the mechanical sieving method. Minced cortex was pressed with a spatula through a stainless steel screen (60-mesh, pore size, $250 \mu$ ) and rinsed successively with PBS through 150-mesh (pore size, $150 \mu$ ) and then 200 -mesh (pore size, $75 \mu$ ) screens. Preparations of glomeruli from the 200 -mesh screen were confirmed with a phase contrast microscope to be free of tubular debris. Whole glomeruli were placed in $25 \mathrm{~cm}^{2}$ tissue culture flasks (Falcon Plastics, Lincoln Park, NJ, USA) with $5 \mathrm{ml}$ of RPMI 1640 (Flow Lab., North Ryde, N.S.W., Australia), to which $20 \%$ heat-inactivated fetal calf serum (FCS, Hyclone Lab., Logan, UT, USA) and $200 \mathrm{mU} / \mathrm{ml}$ bovine insulin (Shimizu pharmaceutical Co., Shimizu) were added. The flasks were incubated in a humidified atmosphere of $5 \% \mathrm{CO}_{2}$ in air, at $37^{\circ} \mathrm{C}$. Half of the conditioned media was changed with fresh media twice a week, and the old culture medium was stored at $-20^{\circ} \mathrm{C}$ until the assay of EPO activity. Glomerular cell overgrowths were subcultured after treatment with PBS containing $0.01 \%$ trypsin and $0.008 \%$ EDTA on day 21 after the first inoculation. Thereafter, glomerular cell overgrowths were subcultured every twenty-first day. One glomerular cell culture was derived from the kidneys of two-to-three Wistar rats of the same age. The cells in the culture were tested for fibroblast contamination by their ability to grow in MEM D-Val (Gibco laboratories, Chargrin Falls, $\mathrm{OH}, \mathrm{USA}$ ) containing $15 \%$ dialized FCS and nonessential amino acid (Gilbert and Migeon 1975).

\section{Immunofluorescence procedure}

To evaluate the nature of the cultured glomerular cells, the cells were grown on slide chambers and fixed in acetone at $4^{\circ} \mathrm{C}$ for $5 \mathrm{~min}$. They were stained using antibodies against glomerular basement membrane (GBM, rabbit antiserum to rat GBM), keratin (rabbit antiserum to human keratin, DAKO, Santa Barbara, CA, USA), actin (rabbit antiserum to chicken gizzard actin, Biomedical Technologies Inc., Cambridge, MA, USA), fibronectin (rabbit antiserum to human fibronectin, Behringwerke AG, Marburg, FRG) and desmin (rabbit antiserum to chicken desmin) by indirect immunofluorescence studies. Rabbit antiserum to rat GBM was prepared as previously described (Ito et al. 1981). Desmin was kindly provided by Dr. R. Kobayashi (the Second Biochemistry Dept., Akita Univ.).

\section{Transmission electron microscopy}

Cultured cells were fixed in $2.3 \%$ buffered glutaraldehyde and post-fixed in $1 \%$ osmic acid, dehydrated in graded alcohol and embedded in epoxy resin. Periodic acid silver methenamin (PASM) stain was used for further visualization of mesangial fibrils.

\section{EPO activity assay}

EPO activity of the culture medium was measured by fetal mouse liver cell (FMLC) bioassay in vitro according to a modification of the technique of Dunn et al. (1975). Fetal liver cells were obtained from dd-Y mouse embryos after 14 days of gestation, and were suspended in Eagle's Minimal Essential Medium (MEM, Gibco, Grand Island, NY, USA) containing $5 \%$ FCS. The culture tubes with $1 \mathrm{ml}$ cell suspension (10\% of them being test samples) were preincubated for $24 \mathrm{hr}$ at $37^{\circ} \mathrm{C}$ in a $\mathrm{CO}_{2}$ incubator. $0.5 \mu \mathrm{Ci}^{59} \mathrm{Fe}$-ferric citrate was subsequently added to each culture tube. Following $4 \mathrm{hr}$ of further incubation, heme was extracted. Radioactivity in the aliquots of the solvent layer was then determined by an autowell gamma-counter. A minimum of three cultures was set up for each sample. 
Sheep plasma EPO (Step III, Connaught Lab., Ontario, Canada) was used throughout this study. The test sample, which was the conditioned medium that was suspended with either RPMI 1640 or MEM + 20\% FCS + Insulin $200 \mathrm{mU} / \mathrm{ml}(0.1 \mathrm{ml}$ of them $2.5 \mathrm{ml})$, was assayed. The details have been reported elsewhere (Fukushima et al. 1984).

\section{Statistical analysis}

The Student's $t$-test was used for statistical comparisons. All results were given as means \pm S.E.

\section{Results}

Characterization of the cells in culture

Two cell types were identified by phase contrast microscopy. On day 3 of the culture, epithelial-like cells ( $\mathrm{E}$ cells) were observed around the explanted glomeruli attached to the bottom of the culture flask. Fig. 1 shows E cells on day 8 by phase contrast microscopy. E cells had an epithelial morphology (a polyhedral shape) and a cobblestone-like appearance when they reached confluency. Immunofluorescence studies showed that $\mathrm{E}$ cells were positive for keratin, GBM, actin, and fibronectin, while they were negative for desmin. Cillia arising from $\mathrm{E}$ cells were recognized by electron microscopic observations. The number of $\mathrm{E}$ cells reached its maximum on about day 8 . Thereafter, E cells decreased rapidly. E cellls did not come to complete confluency, and the subculture of E cells was not successful.

Fibroblast-like cells ( $\mathrm{M}$ cells) appeared at the same time as the E cells. M

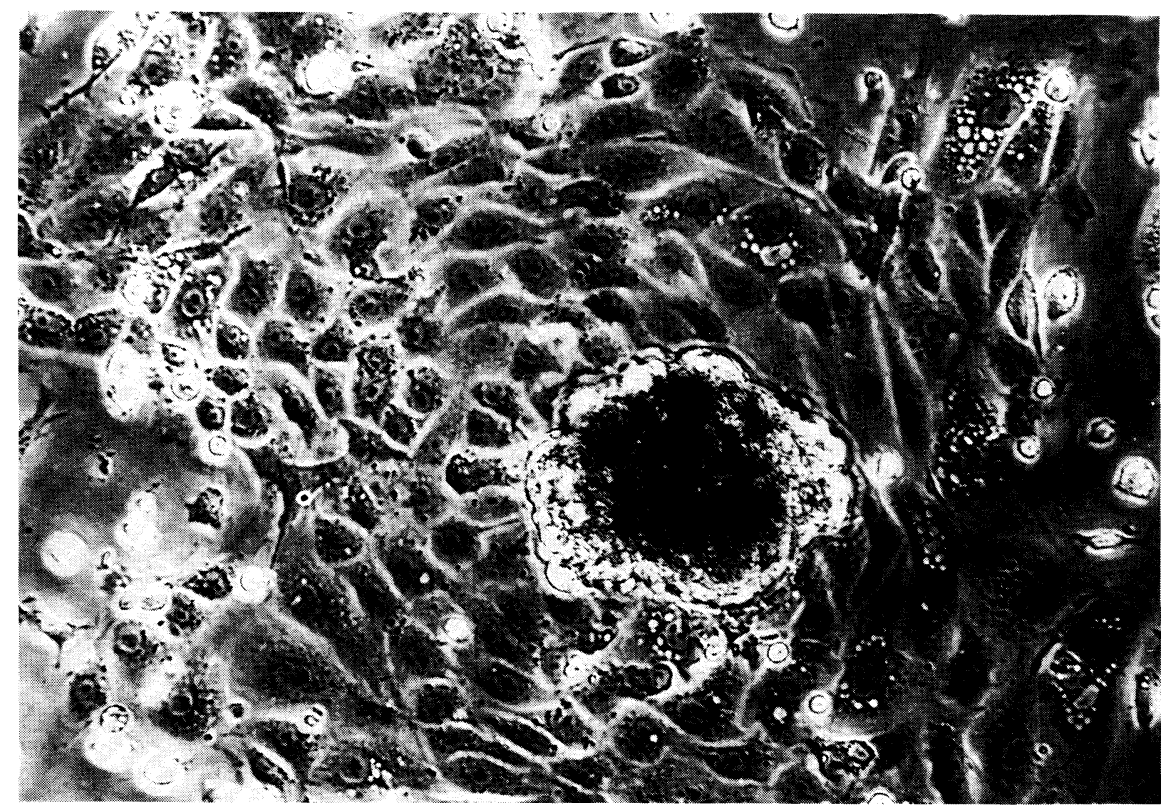

Fig. 1. E cells on day 8 , seen by phase contrast microscopy $(\times 75)$. 


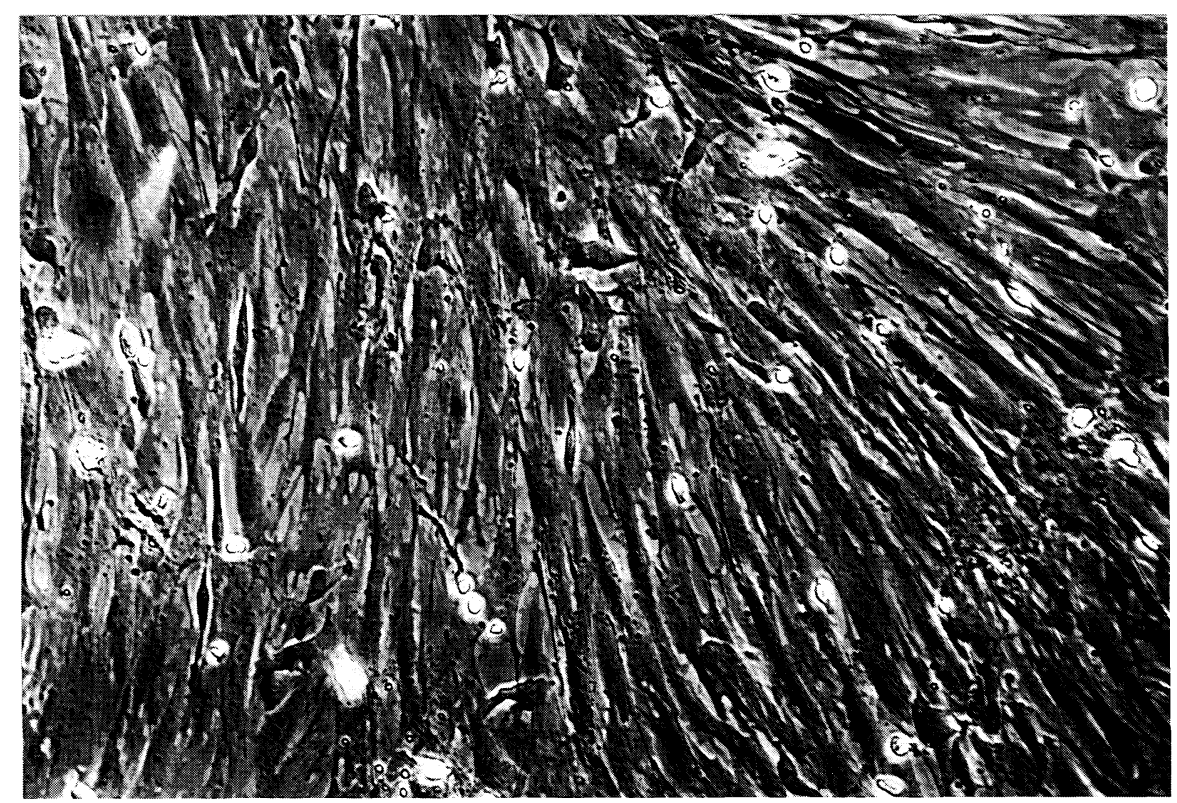

Fig. 2. M cells on day 15 , seen by phase contrast microscopy $(\times 75)$.

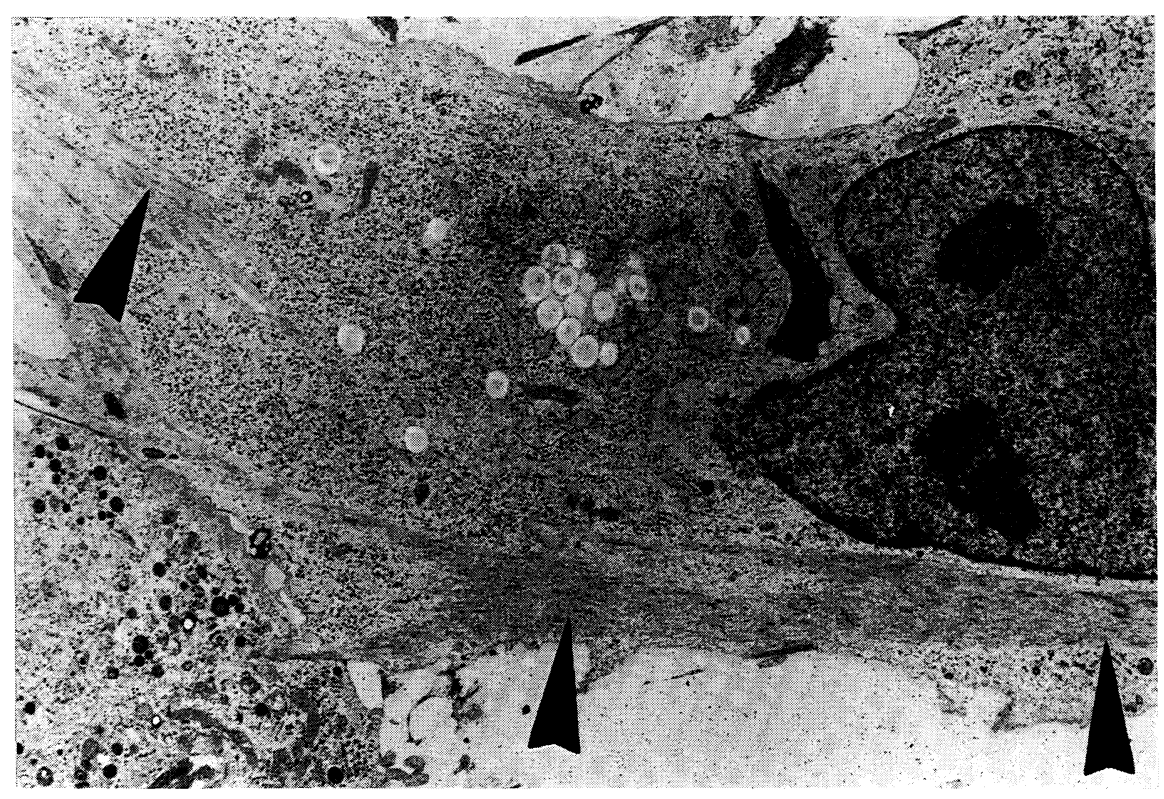

Fig. 3. An M cell seen by transmission electron microscopy. Arrows indicate bundles of microfilaments (original magnification $\times 2,250$ ). 
cells spread rapidly from days 8-10, and E cells were not recognizable on day 14. $\mathrm{M}$ cells came to complete confluency at 14 to 21 days. From days 3 through 10 , E cells were the predominant cell type. From days 10 through 14, E and M cells were mixed in a culture flask. However, the number of $\mathrm{M}$ cells was much greater than the number of E cells. From days 14 through 21, M cells were the predominant cell type. We therefore defined this time as the M-cell proliferating phase in the primary culture. Fig. 2 shows $\mathrm{M}$ cells on day 15, using phase contrast microscopy. M cells were positive for GBM, actin, fibronectin, and desmin, and negative for keratin according to immunofluorescence studies. Fig. 3 shows an M cell, using transmission electron microscopy. The cells had abundant fine filamentous structures running mostly parallel to the long axis of the cell. A subculture of M cells was easily made. After the subculture on day 21 glomerular cells consisted of $\mathrm{M}$ cells alone. Approximately 7 days after every subculture $\mathrm{M}$ cells reached confluency. This period was defined as the proliferating phase in the subculture.

We checked the culture cells for fibroblast contamination by maintaining them in MEM D-Val $+15 \%$ dialized FCS + nonessential amino acids. Because fibroblasts do not grow in D-valine-containing media, we confirmed that the culture cells were not fibroblasts.

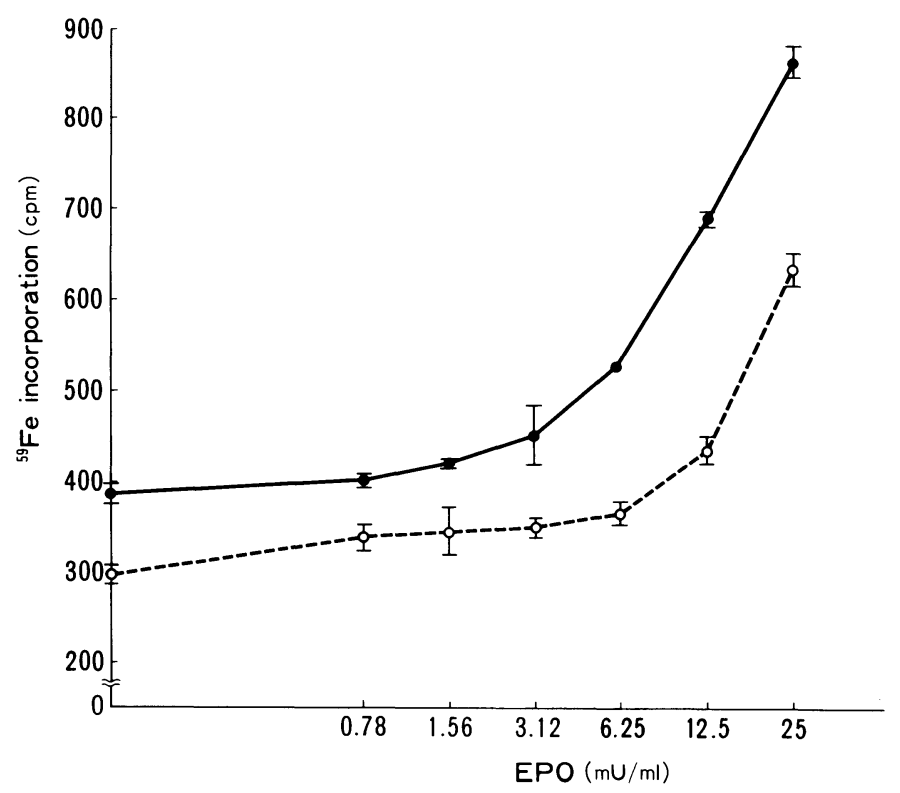

Fig. 4. Dose-response curves for EPO in FMLC assay. Test sample is $0.1 \mathrm{ml}$ in each culture tube with $1 \mathrm{ml}$ cell suspension that contains various concentrations of EPO suspended in RPMI $1640+20 \%$ FCS + insulin $200 \mathrm{mU} / \mathrm{ml}$,

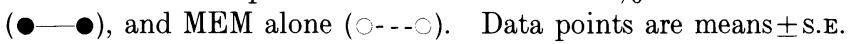




\section{EPO activities in cultured glomerular supernatants}

When EPO activities of sera were measured by FMLC assay, the formula of de Klerk et al. (1978) was used to cancel the influence of non-radioactive iron in the samples. In these experiments, however, each supernatant of culture media had a constant concentration of non-radioactive iron, since FCS of the same lot number was used throughout these studies. Therefore, we were able to measure EPO activities in the culture media directly by the dose-response curves of EPO. Fig. 4 shows the dose-response curves for 2 kinds of sample sera. One shows various concentrations of EPO suspended in RPMI 1640, 20\% FCS and insulin (equal to culture media), and the other shows EPO suspended in MEM alone. The sensitivity of this assay increased when the former suspension was used. The minimum dose of EPO detectable in this assay was $0.78-1.56 \mathrm{mU} / \mathrm{ml}$.

We examined EPO activities in the cultured glomerular supernatants of 6 different glomerular cell cultures. There were three kinds of changes in EPO activities with the passage of time: (1) EPO activities in the culture media during a certain interval (cultures 1, 2, 3, 4), (2) EPO activity only at one time (culture 5), and (3) no EPO activity (culture 6). Fig. 5 shows EPO activities in the supernatants of cultured glomerular cells from 14-week-old Wistar rats (cul-

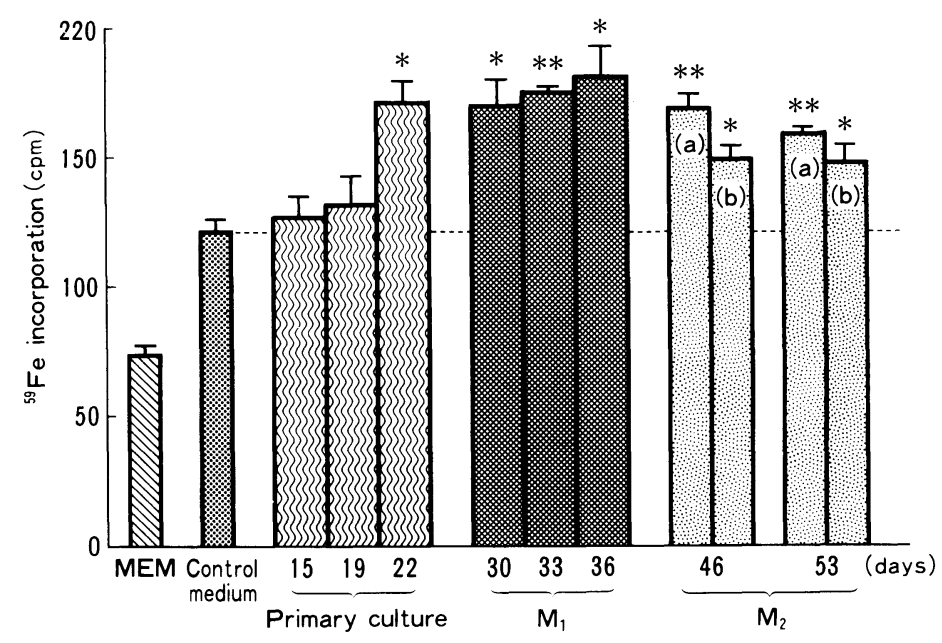

Fig. 5. EPO activities in culture media of 14-week-old Wistar rats (culture 1). $\mathrm{M}_{1}$ means the first-passage subculture and $\mathrm{M}_{2}$ means the second-passage subculture. At the first-passage subculture, $1.05 \times 10^{5}$ free mesangial cells per flask were seeded, and at the second-passage subculture two different cell numbers of $\mathrm{M}$ cells per flask were seeded; (a) $5.0 \times 10^{4}$ cells/flask, (b) $1.0 \times$ $10^{5}$ cells/flask. Single asterisk indicates a significant increase at $p<0.05$ compared with the control medium (RPMI 1640 supplemented with $20 \%$ FCS and insulin), and double asterisks indcate a significant increase at $p<0.01$ compared with the control medium. Bars inicate s.E. of ${ }^{59} \mathrm{Fe}$ incorporation. These marks were also used in Figs. 6 and 7. 
ture 1). Significant EPO activities in the culture media were found from days 22 through 53 (the end of observation). The peak of EPO activities was found on day 36 (the first-passage subculture). This is a representative cell culture of this group. Significant EPO activities in the culture media of 4-week-old Wistar rats (culture 2) were observed from days 21 through 42, and the peak of EPO activities occurred on day 28 (the first-passage subculture). EPO activities in the culture media of 8-week-old Wistar rats (culture 3) were present from days 17 through 77

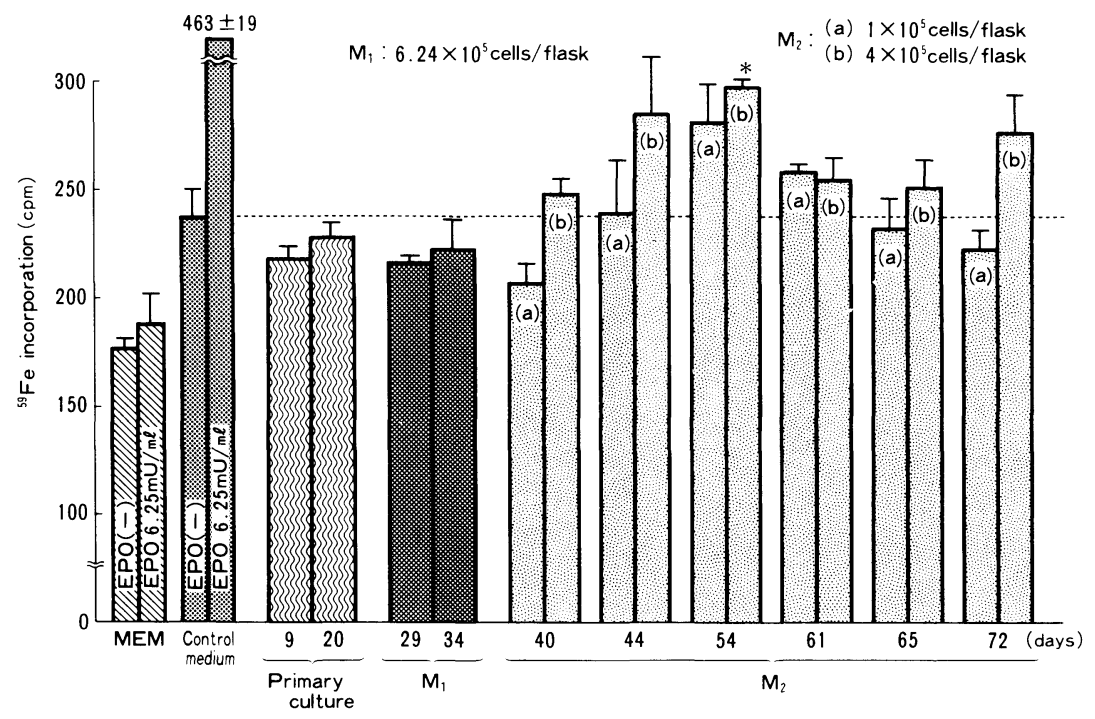

Fig. 6. EPO activities in culture media of 8-week-old Wistar rats (culture 5). ${ }^{*} p<0.05$

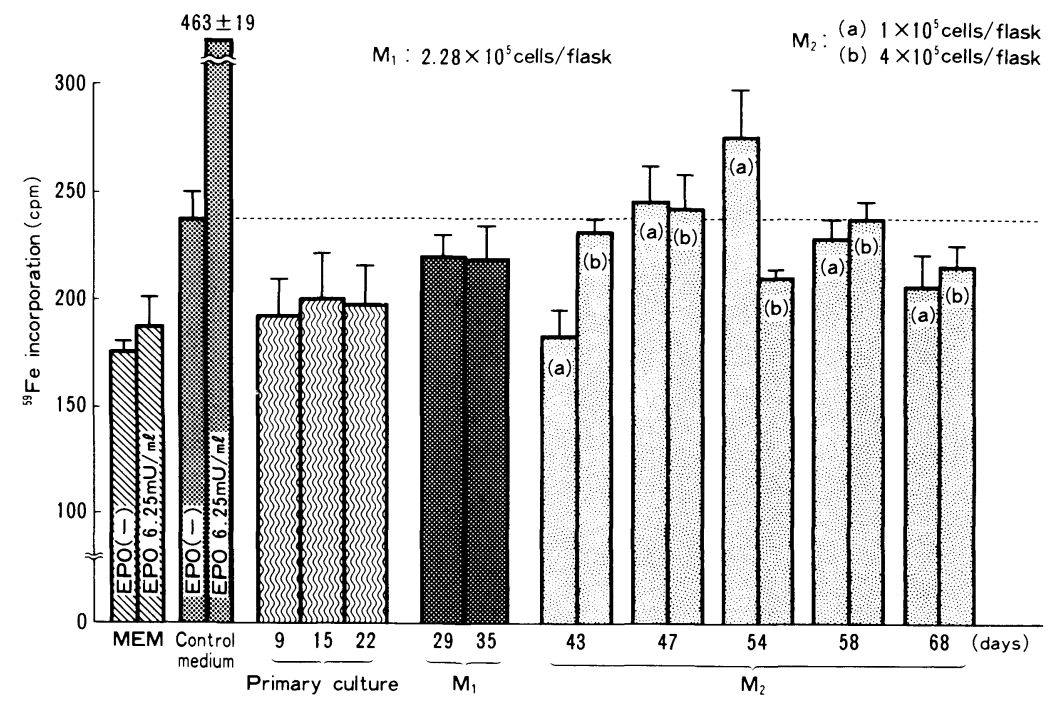

Fig. 7. EPO activities in culture media of 15-week-old Wistar rats (culture 6). 
(the end of observation), and the peak was unclear, although EPO activities were evenly seen entirely throughout these periods. EPO activities in the culture media of 13-week-old Wistar rats (culture 4) were recognized from days 14 through 35, and EPO activities in this culture were also evelny seen during the same period. These EPO activities were estimated to be below $2.0 \mathrm{mU} / 0.1 \mathrm{ml}$, and were detected only when the M cells were fully proliferating. Fig. 6 depicts EPO activities in the supernatants of cultured glomerular cells from 8-week-old Wistar rats (culture 5). Significant EPO activity was detected only in the supernatant of day 54. Fig. 7 illustrates EPO activities in the supernatants of cultured glomerular cells from 15-week-old Wistar rats (culture 6). In this series, no significant EPO activity was detected, and ${ }^{59} \mathrm{Fe}$ incorporation was rather suppressed throughout the observation period except for days 47 through 54 .

\section{Discussion}

Saying that the production site of EPO is in the kidney has been a controversial issue. Glomeruli have been regarded as the most possible site, but the exact site or cell has not yet been determined. Different methods have been utilized to study the EPO production site: isolated perfused organs, incubated tissue slices, incubated cell suspensions, and cell cultures (Jelkmann et al. 1986).

Glomerular cell cultures have enabled us to study homogeneous populations of cells without having the influence of other glomerular cells and extracellular factors, although the cultured glomerular cells may show phenotypic modulation (Kreisberg and Karnovsky 1983). It is likely that E cells come from glomerular epithelial cells as evidenced by phase contrast, immunofluorescent, and transmission electron microscopy. It also seems quite certain that this cell type is not a parietal epithelial cell, since very few isolated glomeruli contained Bowman's capsule. On the contrary, it is hard to determine the origin of $M$ cells. Differentiation between $\mathrm{M}$ cells and fibroblasts is difficult. However, Bachmann et al. (1983) have recently demonstrated the coexistence of vimentin and desmin only in glomerular and extraglomerular mesangial cells. Yaoita et al. (1985) also stated that mesangial cells could be distinguished in vitro from vascular smooth muscle cells and fibroblasts by indirect immunofluorescence studies using antibodies against Thy-1 antigen, desmin, and chicken gizzard actin. $M$ cells in the present study were positive for desmin and intensely stained for actin. Moreover, electron microscopy showed that they had many bundles of small filaments. These results indicate that the present $M$ cells are derived from mesangial cells. Because the subculture of cultured epithelial cells were not successful, cloned homogeneous epithelial cells were not isolated.

We have investigated the EPO activities in the exchanged media of 5 out of 6 cell cultures with the passage of time. Four cell cultures (cultures 1, 2, 3, 4) showed significant EPO activities in the culture media from day 14 (the shortest day) to day 77 (the longest day of the observation period). The peaks of EPO 
activities were present at the end of the primary culture (day 21) or the period of the first-passage subculture. EPO activities tended to decrease after that. One cell culture (culture 5) exhibited significant EPO activity olny in exchanged media at day 54. One cell culture (culture 6) showed no significant EPO activity. However, the change of EPO activities in the culture media of culture 5 and culture 6 bore a striking resemblance. The reason why culture 6 had no significant EPO activities is unclear.

Studies using isolated glomeruli for cultures have also been performed by a few researchers. Burlington et al. (1972) observed in vivo active EPO in longterm cultures of goat glomeruli. The nature of the cell type they described as being in their cultures has not been clearly defined. Our results are consistent with those of Kurtz et al. (1983). Since we have not studied the chemical properties of the EPO activity in culture media, we have not been able to prove that EPO activities are native EPO. However, we were able to assay nonconcentrated samples in the FMLC assay in a series. Among the supernatants of glomerular cell cultures, another substance which can be detected along with EPO activities in the FMLC assay is prostaglandin $(\mathrm{PG}) \mathrm{E}_{2}$. However, we found that $\mathrm{PGE}_{2}$ cannot be detected as EPO activity without the addition of EPO in the culture media (Y. Fukushima, unpublished observations). Therefore, we think that EPO is produced by mesangial cell cultures. Moreover, we demonstrated that specific fluorescent staining could be seen in the mesangial regions using the immunofluorescent antibody technique (Y. Fukushima, in preparation).

We have demonstrated EPO activities in 5 independent mesangial cell cultures. The mesangial cells are not a homogenous cell group. The mesangium has been shown to contain at least two functionally distinct subgroups of cell types both in vivo and in vitro; one resembles a macrophage, and the other resembles a smooth muscle cell (Striker and Striker 1985). Rich et al. (1982) proposed that macrophages might function as local producers of EPO in bone marrow, the spleen, and the liver. Therefore, macrophages might have contributed to the EPO activities in the culture media. However, these cells do not survive long in culture (Kreisberg and Karnovsky 1983; Striker and Striker 1985). It is necessary to study whether EPO is secreted by all mesangial cells, or by only some specific cells among them. Work on this question is currently in progress.

In conclusion, we observed EPO activities in the culture media from the primary mesangial outgrowth and the first- and second-passage subculture, but not from epithelial cell outgrowth. Therefore, mesangial cells seemed to be EPO producing cells.

\section{Acknowledgments}

We would like to thank Dr. Eishin Yaoita and Prof. Itaru Kihara (Niigata University) for kind advice about glomerular cell culture.

This study was partly supported by Grant for Scientific Research (No. 59770439) from 
the Ministry of Education, Science and Culture, Japan.

\section{References}

1) Bachmann, S., Kriz, W., Kuhn, C. \& Franke, W.W. (1983) Differentiation of cell types in the mammalian kidney by immunofluorescence microscopy using antibodies to intermediate filament proteins and desmoplakins. Histochemistry, 77, 365-394.

2) Burlington, H., Cronkite, E.P., Reincke, U. \& Zanjani, E.D. (1972) Erythropoietin production in cultures of goat renal glomeruli. Proc. Natl. Acad. Sci. USA, 69, 35473550 .

3) de Klerk, G., Hart, A.A.M., Kruiswijk, C. \& Goudsmit, R. (1978) Modified method of erythropoietin (ESF) bioassay in vitro using mouse fetal liver cells. II. Measurement of ESF in human serum. Blood, 52, 569-577.

4) Dunn, C.D.R., Jarvis, J.H. \& Greenman, J.M. (1975) A quantitative bioassay for erythropoietin using mouse fetal liver cells. Exp. Hematol., 3, 65-78.

5) Erslev, A.J. \& Caro, J. (1984) Secondary polycythemia: A boon or a burden? Blood Cells, 10, 177-191.

6) Fisher, J.W., Taylor, G. \& Porteous, D.D. (1965) Localization of erythropoietin in glomeruli of sheep kidney by fluorescent antibody technique. Nature (Lond.), 205, 611-612.

7) Fukushima, Y., Miura, I., Takahashi, T., Fukuda, M., Kosaku, Y., Yamaguchi, A. \& Miura, A.B. (1984) Serum erythropoietin (ESF) levels and erythroid progenitors (CFU-Es) of patients with chronic myeloproliferative disorders. Tohoku J. Exp. Med., 142, 399-407.

8) Foidart, J.B., Dechenne, C.A. \& Mahieu, P. (1979) Tissue culture of normal rat glomeruli. Isolation and morphological characterization of two homogeneous cell lines. Invest. Cell Pathol., 2, 15-26.

9) Gilbert, S.F. \& Migeon, B.R. (1975) D-valine as a selective agent for normal human and rodent epithelial cells in culture. Cell, 5, 11-17.

10) Hirashima, K. \& Takaku, F. (1962) Experimental studies on erythropoietin. II. The relationship between juxtaglomerular cells and erythropoietin. Blood, 20, 1-8.

11) Ito, M., Nagamatsu, T. \& Suzuki, Y. (1981) Pharmacological studies on experimental nephritic rats (10). Changes in coagulation-fibrinolysis system in the course of anti-GBM induced nephritis. Jpn. J. Nephrol., 23, 297-308. (in Japanese with English abstract)

12) Jacobson, L.O., Goldwasser, E., Fried, W. \& Plzak, L. (1957) Role of the kidney in erythropoiesis. Nature (Lond.), 179, 633-634.

13) Jelkmann, W., Kurtz, A. \& Bauer, C. (1986) In vitro production of erythropoietin. In: Kidney Hormones, Vol. III, edited by J.W. Fisher, Academic Press, London, pp. 559-583.

14) Kreisberg, J.I. \& Karnovsky, M.J. (1983) Glomerular cell in culture. Kidney Int., 23, 439-447.

15) Kurtz, A., Jelkmann, W., Sinowatz, F. \& Bauer, C. (1983) Renal mesangial cell cultures as a model for study of erythropoietin production. Proc. Natl. Acad. Sci. USA, 80, 4008-4011.

16) Rich, I.N., Heit, W. \& Kubanek, B. (1982) Extrarenal erythropoietin production by macrophages. Blood, 60, 1007-1018.

17) Striker, G.E. \& Striker, L.J. (1985) Biology of disease. Glomerular cell culture. Lab. Invest., 53, 122-131.

18) Yaoita, E., Kazama, T., Kawasaki, K., Miyazaki, S., Yamamoto, T. \& Kihara, I. (1985) In vitro characteristics of rat mesangial cells in comparison with aortic smooth muscle cells and dermal fibroblasts. Virchows Arch. [B], 49, 285-294. 